Ирена Пантић*

ОШ „Димитрије Туцовић“ Краљево

Висока економска школа

струковних студија Лепосавић

\section{Иван Петровић}

Економско-трговинска школа Краљево
371.3::811.134.2'243

https://doi.org/10.18485/ziv-

jez.2020.40.1.9

Стручни рад

\title{
ГРЕШКЕ КОЈЕ УЧЕНИЦИ ЗАВРШНИХ РАЗРЕДА ОСНОВНЕ И СРЕДЊЕ СТРУЧНЕ ШКОЛЕ ПРАВЕ НА ЕНГЛЕСКОМ ЈЕЗИКУ
}

Циљ рада је идентификација и анализа грешака које ученици енглеског језика праве у завршним разредима основне и средње стручне школе. Одгонетају се разлози који доводе до њиховог настанка, посматрани у српском језичком контексту. Материјал за рад обезбеђен је праћењем говора ${ }^{1}$ и писања ученика. Разврстан је на лексичко-прагматичке, морфолошко-правописне и синтаксичке грешке. Тиме желимо да покажемо да језичке грешке треба посматрати као позитиван показатељ у настави, као алат у унапређењу језичких вештина ученика.

Кључне речи: језичка грешка, језички утицај, енглески као страни језик, српски као матерњи језик, језички трансфер, семантика.

\section{1. Увод}

Језичком грешком, најгрубље речено, сматра се одступање од норми циљног језика (Елис 1994: 51). То су она одступања која настају због недостатка знања о конкретном правилу (Кордер 1967: 961). Неки лингвисти (Џејмс 1989: 1) језичке грешке сматрају особином људске посебности. Човека, поред

* irenapantic01@gmail.com

1 Овде се нећемо бавити квалитетом говора у фонолошком, већ само у структуралном смислу, иако је и изговор гласова Л2 (енглеског) на овом нивоу под утицајем гласова Л1 (српског). 
homo sapiens и homo loquens зову и homo errans, а језичку грешку неуспешним делићем језика. Дакле, овде говоримо о погрешкама које ученици праве, а које не умеју сами да исправе, па им је стога неопходно објашњење (Хармер 2007: 96). Анализом језичких грешака и откривањем разлога њиховог настанка бави се истоимена научна област (енг. error analysis) у оквиру контрастивне лингвистике. Узроци који доводе до њиховог настанака су вишеструки, мада су углавном последица разнородности језичких система (Ђорђевић 2004: 3).

Интересовање научника за анализу грешака није нововремена појава. Датира од средине XX века (в. Ли 1957; Ламберт 1966; Керол 1966; Чомски 1966; Кордер 1967; 1981; Душкова 1969). Међутим, разврставање и груписање грешака су област гдесумишљења аутора и данас врло различита.Душкова (1969) увиђа да је утврђивање категорија врло захтевно, па грешке најпре дели на системске (енг. recurrent systemic errors) и тренутне (енг. nonce errors), а потом врши потподелу према лингвистичким категоријама речи. Полицер и Рамирес (1973) имају три врло широко постављене групе: морфолошке, синтаксичке и грешке вокабулара. Барт (1975) дели грешке у три опште категорије: развојне (енг. developmental), сличне грешкама деце при усвајању Л1, грешке међуделовања језика (енг. interference), које рефлектују структуре Л1 на Л2, и јединствене (енг. unique) које не припадају претходним двема. Кордер (1981: 36) прави четири категорије: грешке омисије (енг. errors of omission) представљају одсуство битних језичких елемената у језичком изразу, грешке адиције (енг. errors of addition) присуство непотребних језичких елемената, грешке селекције (енг. errors of selection) избор погрешног језичког елемента на исправном месту и грешке у редоследу (енг. errors of ordering) које се догађају када су присутни елементи исправни али неправилно распоређени. Далеј и сарадници (1982: 150) су грешке које се најчешће јављају разврстали у четири категорије, и то на: лингвистичку категорију (енг. linguistics category taxonomy), категорију површинске стратегије (енг. surface strategy taxonomy), компаративну (енг. 
comparative taxonomy) и категорију комуникативног ефекта (енг. communicative effect taxonomy). Лингвистичка категорија класификује грешке према језичкој компоненти на коју утичу - фонологија, синтакса, морфологија, семантика, лексика и дискурс. Категорија површинске стратегије разликује начине на које је измењена површинска структура: омисија (нпр. флективних наставака, чланова, помоћних глагола, предлога), адиција (присуство непотребних језичких јединица, што је индикатор да су основна правила Л2 донекле усвојена), употреба погрешних облика (нпр. неконгруирање једнине и множине, енг. misform) и погрешан поредак речи или морфема (енг. misorder). Компаративна категорија пореди структуре грешака на Л2 са другим типовима конструкција (слично развојним грешкама деце у процесу усвајања Л1 и интерлингвалном утицају структура из Л1 на семантичке еквиваленте Л2). Комуникативна категорија се односи на грешке које доводе до неразумевања (енг. miscommunication).

И новија истраживања (в. Ричардс и Шмит 2002: 267) виде грешкукао резултат погрешногилинепотпуногучења.Групишу их у следеће категорије: прекомерну генерализацију или хиперкорекцију (енг. overgeneralizations), поједностављивање тј. упрошћавање језичких форми, омисију, адицију (енг. simplifications), развојне грешке (енг. developmental errors) које подразумевају непримењивање научених правила, индуковане грешке (енг. induced errors) - неуважавање одступања од правила, грешке избегавања (енг. errors of avoidance) и грешке прекомерне продукције (енг. errors of overproduction) где долази до честог понављања одређених структура.

Иако је из свега наведеног јасно да интересовање за анализу грешака није ретка ни нововремена појава, верујемо да би њено конкретизовање и контекстуализовање могло да има значаја у настави енглеског језика у назначеном периоду образовања. Примарни циљ рада нам је откривање и описивање језичких грешака ученика, како би се открио узрок њиховог настанка и смањио њихов број. Надамо се да се на тај начин може допринети планирању рада на часу и олакшати 
одређивање мера које би довеле до унапређивања језичке продукције ученика. А за унапређивање техника и ефеката наставе, дијагностика и третман језичких грешака неки су од фундаменталних квалитета наставника (Кордер 1981: 35). Секундарни циљ нам је да покушамо да осветлимо неке од начина на који српски, као претходно усвојени језички систем, утиче на ниво усмене и писане продукције на енглеском као страном језику.

Корпус за рад обезбеђен је на часовима енглеског језика током две школске године (2018/19. и 2019/20), са ученицима у једној основној (VII и VIII разред) и једној средњој стручној школи (I - IV разред економске школе). Прикупљени материјал темељи се на белешкама наставника током припремљеног усменог излагања ученика на задате теме, анализи есеја на задате теме, анализи писања приче од задатих речи, описивања слике, писаних одговора на питања и др. У обзир су узети сви примери који су се понављали, тј. јавили више од једног пута (учесталост појављивања грешака варирала је од 6 до 19 пута).

Ученици из нашег истраживања припадају генерацијама које уче страни језик од првог разреда основне школе 2 , те се може рећи да њихова изложеност настави страног језика траје од седам до дванаест година. Енглески је свакако најпопуларнији и у оквиру формалног и неформалног образовања (Филиповић и сарадници 2007: 235), што чини изложеност језику интезивнијом. То даље значи да се од ученика очекује да ниво њихових језичких компетенција, према скали Заједничког европског референтног оквира (Савет Европе 2001), одговара нивоу А2 (нижи средњи, енг. preintermediate) на крају основне и Б1 (средњи, енг. intermediate) на крају средње струче школе (Вучо и Филиповић 2013: 159). Узорак је узрасно (адолесцентска доб) и жанровски (говор и писање) уједначен, као и степен ученичке језичке способности (A2 - Б1).

2 У основним школама у Србији настава енглеског као страног језик од I разреда основне школе започела је након образовне реформе, школске 2003/04. године. 
Методологија консултованих радова углавном прати Кордерове (1981) кораке у спровођењу анализе грешака: 1. прикупљање језичког узорка, 2. идентификација грешака, 3. опис грешака, 4. објашњење грешака и 5. евалуација грешака. Ми смо овде применили исту методологију (кораци 1, 2, 3 и 4), док се евалуацијом грешака, тј. какав ефекат језичке грешке врше на примаоце поруке, нисмо бавили.

\section{2. Анализа}

Квалитативном анализом корпуса укупан материјал груписали смо према врсти на лексичко-прагматичке, морфолошко-правописне и синтаксичке грешке. Групе смо формирали према лингвистичкој области којој припадају.

\section{1. Лексичко-прагматичке грешке}

Лексичка прагматика бави се систематичним проучавањем значењских својстава лексике у језичкој употреби (МишковићЛуковић 2015: 103). Управо неусклађено лексичко значење, погрешно усвојена и стога ситуационо погрешно употребљена реч ствара грешку. Ова врста неправилности јавља се у случајевима када је реч употребљена у непримереном језичком контексту, те не поседује капацитет да изнесе намеравани садржај. Будући да се наведено тиче неподударања значења речи са захтеваним смислом, тј. погрешне употребе речи у контексту, ми смо их објединили у групу лексичкопрагматичких грешака.

Ову групу смо репрезентовали примерима:

Глаголски пар borrow/lend - Код ученика се често могу чути и реченица He borrowed me a book. и реченица Can I borrow your pen, please? Ученици не праве битну разлику између смерова радњи, користећи исти глагол и за узимање и за давање на зајам. С друге стране, енглески језик прави јасну дистинкцију између ове две радње. За давање на зајам користи lend, а за узимање на зајам глагол borrow. Верујемо да је овде 
по среди снажан утицај српског језика. Српски у савремено доба лексички изједначава ова два смера позајмљивања, иако је у прошлости у овом смислу прављена јасна разлика између њих, постојањем глагола позајмити (дати на зајам) и узајмити (узети на зајам). Потоњи је, нажалост, временом изгубио актуелност, и данас је на граници архаичности. Корпус савременог српског језика (SrpKor2013) бележи их у односу 1:14 у корист позајмити (узајмити 7, позајмити 98 јединица).

Глаголски пар teach/learn - Слично претходном пару, разлика почива у подразумеваном вршиоцу радње. Ученици често дају предност глаголу learn у оба контекста, иако teach указује на наставника, предавача као вршиоца радње, a learn на ученика. У реченици He teaches, јасно је да се ради о наставнику, a y He learns, јасно је да се ради о ученику. Разлог налазимо у утицају српског, где је глагол подучавати прави формални кореспондент глаголу teach, али су му фреквенција и опсег у српском знатно ређи. Износе 1:23 у корист глагола учити, који у српском покрива оба концепта (SrpKor2013: подучавати 26, учити 598 јединица).

Глаголски пар call/invite - Честа је супституција глагола invite глаголом call, па ученици у значењу He invited me to England. кажу He called me to England. По свој прилици, узрок је српски глагол позвати којим се и invite (упутити позив) и call (зовнути, звати) најчешће преводе на српски. Иако се позвати и зовнути могу сматрати у великој мери синонимима, учесталост глагола позвати је 1,5 пута већа (SrpKor2013: позвати 1222, зовнути 799 јединица).

Придевски парови much/many и little/few - Ученици не праве довољно прецизну разлику између ових парова детерминатора, и често један замењују другим. Српски језик не разликује облике придева много и мало када се односе на бројиве и на небројиве именице. Српски чак и не поседује подврсту именица која би била хипероним градивним и мисаоним. Стога се може рећи да корен ове погрешке лежи у немогућности корелације између језика извора и језика циља.

Предлози in/for у прилошким одредбама за време Ученици у намераваном изразу Meet me in 10 minutes. (Нађимо 
се за 10 минута) који се односи на период након којег ће се десити изречена радња, уместо предлога in користе предлог for. Тиме се добија израз Meet me for 10 minutes. (Нађимо се на 10 минута) којим се имплицира дужина трајања исказане радње, што није била намера. По свему судећи, узрок је директан превод српског предлога за који у овом значењу није компатибилан са енглеским.

Честа је замена предлога у временским изразима са данима у недељи, као in Monday - on Monday, у начинским изразима са превозним средствима with car - by car, у изразу it depends of - it depends on. Такође се показало често коришћење различитих предлога уз глагол gо. Српски језик има разгранату понуду предлога уз глагол ићи (ићи у, ићи на, ићи код, ићи до...), док је у енглеском први и најобухватнији предлог у локативном и циљном смислу, предлог to. He is going to London. He is going to work. He is going to his friend's. He is going to a supermarket. За сваку од наведених грешака при избору одговарајућег предлога уз глагол go, сматрамо да разлог лежи у језичком трансферу из српског, и занемаривању енглеске лексичке стварности. Исто се дешава и са глаголом come, где предлог to бива неоправдано замењиван бројним другим предлозима.

Глаголи take, eat, drink за узимање хране и пића често код ученика добијају предност над глаголом have, који је у овом смислу пожељнији у енглеском језику. Користи се Let's drink coffee, уместо Let's have a cup of coffee; I eat breakfast at 8, уместо I have breakfast at 8; I took a sandwich for breakfast, уместо I had a sandwich for breakfast. Верујемо да и овде разлог лежи у дословном превођењу мотивисаном српским језиком (drink coffee) и недовољној усвојености енглеских колокацијских склопова (have breakfast, have a sandwich).

Питање Doyou mind? најчешће се користи за учтиво тражење дозволе (у зависности од интонације, може да изрази љутњу). Чест, а неправилан одговор буде Yes, of course, због директне аналогије са српском конструкцијом која се користи у истом говорном контексту Могу ли да...? Исправан одговор, којим се даје тражена дозвола требало би да буде No, of course not. 
Лексички парови advice/advise, practice/practise, licence/ license - облици на -ice по врсти су именице, а на -ise глаголи. Ученици углавном не осећају довољну издиференцираност између ове две врсте речи. Разликовање додатно отежава поједностављеност америчког стандарда, где се именички облик practice профилисао као униформан за обе врсте, као и глаголски облик license за обе врсте. За британску варијанту ова униформност не важи.

Придев good и прилог well - нестандардна је замена прилога well придевом good, као у примеру How are you? - I'm doing good, уместо I'm doing well (или I'm good). Претпостављамо да узрок лежи у малој морфолошкој разлици између српског придева добар и прилога добро, а придев је, у оба језика, знатно фреквентнији. Стога ученици уопштавају придев good, те он преовладава и у прилошкој употреби у енглеском језику.

\section{2. Морфолошко-правописне грешке}

Други тип грешака чине морфолошко-правописне грешке. Ову врста грешака чине језичке неправилности морфолошког карактера, у смислу конгруенције, неправилне творбе речи и непримењивања правописних правила које ти процеси налажу.

Међунајчешћимјенеслагањеодноснезаменице who сародом именице на коју се односи. У енглеском све именице које имају аниматни ентитет мушког су или женског рода, а неаниматни средњег рода. Основно правило о разликовању односних заменица who и which упућује да се who користи за изражавање припадности аниматним именицама, а which за припадност неаниматним именицама. У ученичкој пракси заменица who доминира, без обзира на аниматност именица. Тако се често cpeћe The car who she drove yesterday (...) Претпоставља се да неиздиференцираност ове две заменице има везе са српском упитно-односном заменицом који која се равноправно користи за именице које означавају и живе и неживе појмове.

Слично неслагање у роду присвојног придева и именице на коју се придев односи, присутно је у доминантној употреби 
придева his/her према придеву its. Често се чује her door за школска врата, his tail за псећи реп, her cover за књишке корице итд. Верујемо да је и овде посреди утицај српског језика, који поред природног, за разлику од енглеског, поседује и граматички род. Тако именица која се односи на неживи/ неаниматни појам може у српском да буде у било ком од три рода, док је у енглеском за њих искључиво резервисан средњи роди и присвојни придев its.

Различите врсте речи (именице, глаголи, придеви) које се завршавају на -у којем претходи сугласник, при флексији мењају -y у -i- испред наставака -s (за множину именица и за треће лице једнине презента глагола), -ed (за прошло време правилних глагола) и -er/-est (за компаратив и суперлатив придева). Тако налазимо babys (уместо babies), crys и cryed (уместо cries и cried), happyer и happyest (уместо happier и happiest). Друга крајност је хиперкорекција - примена правила и на случајеве где поменута правописна промена није стандардна, као у tois (уместо toys), plais и plaied (уместо plays и played), graier (уместо grayer).

Пропусте у правописним променама при морфолошким процесима нашли смо и у деривацијским процесима. Суфикс -ful за извођење придева од именица често се неоправдано пише са двоструким $l$. Налазимо wonderfull уместо wonderful, beautifull уместо beautiful, carefull уместо careful итд. Узрок овоме је двојак. Први је ортографска и семантичка сличност суфикса са иначе честим ${ }^{3}$ придевом full.Други је даље извођење прилога од придева на -ful. Додавањем суфикса -ly добија се прилог, приликом чега не долази до елизије сугласника, већ $l$ остаје удвојено.

У извођењу партиципа и именица од глагола на $-l$ код којих акценат није на последњем слогу ${ }^{4}$ у британском енглеском

3 Према Oxford English Dictionary учесталост придева full је од 1 до 10 понављања у милион речи (5/8), www.oed.com.

4 Оба наречја енглеског, и британско и америчко, фаворизују удвојеност сугласника $l$ у извођењу партиципа од глагола код којих је акценат на последњем слогу, као у con'trolled/con'trolling, ex'pelled/expe'lling, a'nnulled/a'nnulling. 
удваја се l. Ученици, под утицајем америчког правописа, углавном не врше ово удвајање, па су traveled/traveling/traveler, modeled/modeling/modeler, canceled/canceling/cancelation итд. много присутнији од travelled/travelling/traveller, modelled/ modelling/modeller, cancelled/cancelling/cancellation, иако је према употребљеној лексици и ортографији очито да су опредељени за британску варијанту енглеског језика.

Енглеска именица information припада групи небројивих именица, и као таква нема оба броја, тј. има само облик једнине, те захтева глагол у једнини (нпр. is, was, has). Ученици је, под утицајем матерњег језика, често плурализују и пишу са множинским наставком -s, праћену глаголом у множини (are, were, have). Садржај појма који постоји у више него једном примерку може се исказати изразима pieces of information/ lots of information/some information, сваки пут са основном именицом без поменутог множинског наставка.

Међу правописним неправилностима чест је изостанак употребе великог слова уенглеским именицама које означавају називе данау недељи, месецау години и упридевима изведеним од назива држава. Ове грешке вероватно су последица утицаја српског правописа. ${ }^{5}$

Слично неслагање међу језицима постоји у интерпункцијским нормама. Енглески модел писања наводничких и полунаводничких графема прописује горњу позицију и за отварајуће и за затварајуће знаке, док српски модел има отварајући доњи а затварајући горњи положај. Потом, енглески стандард редне бројеве у датуму обележава наставцима, без тачке, док за године употребљава основне бројеве. Овде ученици учестало занемарују разлике, па користе јединствен начин писања на оба језика, и то претежно српски.

5 Као другу крајност, србисти у основним и средњим школама писање великог почетног слова код назива дана у недељи, месеца у години и присвојних придева изведених од назива држава виде као ученичко недоследно разграничавање норми два језика, што доводи до преливање правила једног језика у други. 


\section{3. Синтаксичке грешке}

Последњу групу грешака чине синтаксичке грешке. Српски и енглески, иако припадају истој индоевропској групи језика, потичу из различитих језичких породица - словенске и германске. Стога не постоји потпуна компатибилност између елемената њихових реченичних структура, што је посебно изражено у начину творбе глаголских времена и опсегу њихове употребе. Нису много ређе ни грешке које се тичу неуважавања и нарушавања других синтаксичких правила - реда речи у реченици, организације унутар препричаних питања, вишеструке негације и др. Верујемо да узрок почива у недоследној примени правила, али и у директном преношењу творбених јединица једног језика у други.

Српски језик не врши формалну дискриминацију између уобичајене и тренутне садашњости, па су грешке у изражавању овог аспекта честе и делом очекиване. Изненађује да је бројност грешака овог типа на штету уобичајене (The Present Simple), а у корист тренутне садашњости (The Present Progressive), иако је форма за изражавање уобичајене садашњости једноставнија, а употреба социјално и практично чешћа.

Форма глаголског облика The Present Progressive (I am living here for 5 years) неоправдано се користи у случајевима изражавања процеса који осим садашњег момента подразумевају и одређени период трајања радње у прошлости (I have lived here for 5 years). Како српски језик не поседује кореспондентну форму којом би се повезала и објединила ова два периода радње, избор времена мора се вршити према семантици глаголских времена и временским маркерима.

Супротно наведеним примерима неосноване употребе облика The Present Progressive, пракса показује да он изостаје у случајевима када се указује на испланирани будући догађај (We are going to Belgrade tomorrow). Ученици учестало посежу за простом будућношћу (We will go to Belgrade tomorrow), што у овом контексту није оправдано.

Српски језик има релативно релаксиран и флексибилан став према различитим аспектима прошлог времена, те махом 
користи перфекат и за радње окончане и започете у прошлости. Због утицаја матерњег и због његове релативно једноставне форме, ученици доминантно користе просту прошлост (The Past Simple) уместо садашњег перфекта (The Present Perfect) у случајевима када временски период на који се указује није дефинисан (Did you read War and Peace?), а ни радња окончана (I started reading Ana Karenina), чак и у присуству временских одредница just, yet, already.

У изразима I wish..., If only..., It's high time... и осталим структурама за изражавање хипотетичких и других ситуација које нису засноване на чињеницама, честа је неправилна употреба садашњег времена The Present Simple за ситуације у садашњости где је неопходан The Past Simple, односно The Past Simple за ситуације у прошлости где је неопходан The Past Perfect, нпр. I wish I have a lot of money, уместо I wish I had a lot of топеу. Узрок је неподударање граматичких структура у језицима извора и циља, што је последица разлике у њиховим системима конјугације.

На нивоу синтаксе, јављају се и нестандардне конструкције настале превођењем „реч за реч”, посебно при образовању прошлог пасива. Реченице He is born in England. и The house is built. типични су примери употребе садашњег пасива, a намераване прошлости. Замка настаје изједначавањем помоћног глагола јесам, који се у српском користи за образовање прошлог времена, са глаголом $b e$, који облицима $a m$, is и are увек имплицира садашње време.

Модалност у оба језика категорија је језичког значења за исказивање могућности и неопходности. Модалним глаголима у оба језика заједничка је ${ }^{6}$ особина безличности, на начин да се у српском не користе у другима лицима осим трећег једнине, а у енглеском немају обележје лица у презенту (Мора да... према

6 Различито је што су модали у српском у претпозицији у односу на субјекат (Мора да сам.../Мора да је...), док су у енглеском у постпозицији у односу на субјекат (I must.../He must...). Генерално, модали у српском поседују знатно мање особености у односу на друге чланове глаголског система, него што је то случај у енглеском језику. 
I/He must..., Треба да... према I/He should...). Како су модали у оба језика непотпуни и захтевају допуну, на грешку у употреби енглеских модала утиче допуна која је у српском у облику даклаузе, као у Мора да сте погрешили. Допуна у енглеском мора бити у облику крњег инфинитива, тј. без предлога као у Үои must be wrong, но често се користи пун инфинитив као у You must to be wrong.

Како је распоред језичких елемената (редослед речи) у реченицама у српском језику релативно слободан, субјекат и други реченични чланови могу да се нађу на било којем месту у реченици. Деклинација именских речи у српском недвосмислено супротставља вршиоца радње (номинатив) примаоцу радње (акузатив), па је непрецизност у значењу онемогућена. За разлику од српског, енглески не поседује деклинацију као морфолошку карактеристику, а редослед језичких елемената у енглеском утврђен је у обрасцу субјекатпредикат-објекат, тј. субјекат увек има иницијалан ${ }^{7}$ положај. Свако кршење овог правила има за резултат нејасан и непрецизан израз. Распоред прилошких одредби такође је прописан, у редоследу начин-место-време.

Индиректна питања захтевају реорганизацију реченичних чланова на начин да упитна форма реченице прелази у форму обавештајне, а помоћни глаголи или прелазе иза субјекта (be, have, модални глаголи) или се спајају (do, does, did) са главним. Како се оваква промена не догађа у српском језику, ученици често у енглеском занемаре прелазак упитног облика у обавештајни. Тако питања попут What is the time? буду неправилно пренети He asks me what is the time, уместо He asks me what the time is, а питања попут Who did you meet? - He asks me who did I теet, уместо He asks me who I met.

У енглеском језику двострука негација није нормирана. Супротно, у српском су случајеви двоструке и вишеструке негације оправдани и потребни, уз предуслов одричног предиката. Верујемо да је та негацијска флексибилност

7 Осим када је на почетку реченице неки временски израз. 
матерњег језика узрок нестандардних израза попут He didn't tell me nothing yesterday, уместо He didn't tell me anything yesterday, или чак I haven't never seen nothing like that nowhere, уместо I have never seen anything like that anywhere.

Глаголи suggest и recommend траже допуну у виду именице, that-клаузе или герунда у функцији директног објекта, као у He recommended a book to me, He suggested (that) I (should) see the film. или He suggested going to the cinema. Истицање лица којем су предлог или препорука дати може се извршити допуном to+лице иза објекта. Ученици, под утицајем истозначне конструкције у матерњем језику, стављају допуну to+лице одмах иза глагола, што у енглеском није прихватљиво.

Нису ретки случајеви употребе предлога у оквиру допуне глагола, у конструкцијама где би морали бити изостављени, и обрнуто. У суштини, област предлога је за већину ученика врло нејасна, јер се концепт предлога у енглеском, као и функције које врше, разликују од српског језика. Поред тога, чини се да се проучавању семантике предлога не поклања довољна пажња у основном и средњем стручном образовању. Глаголи discuss, enter, enjoy типични су примери употребе предлога у конструкцијама у којима им није место. Тако, уместо Let's discuss it добијамо Let's discuss about it, уместо He entered the room добијамо He entered in the room, уместо We enjoyed the meal добијамо We enjoyed in the meal. С друге стране, допуне глагола рау и wait примери су конструкција где препозиција неоправдано изостаје. Зато уместо I'll pay for the tickets, налазимо I'll pay the tickets, а уместо We are waiting for the bus, налазимо We were waiting the bus. У сваком од примера имамо језички трансфер, као последицу снажног утицаја матерњег језика.

\section{3. Закључак}

Рад се бави анализом језичких грешака које изворни говорници српског језика праве током учења енглеског кроз систем формалног образовања, на нивоу од нижег средњег 
до средњег. Како смо уочили да корпус чине јединице из различитих језичких области, груписали смо их у три широка скупа, релативно усклађеног обима - лексичко-прагматичке (33\%), морфолошко-правописне (27\%) и синтаксичке грешке (40\%).У смислуузорака који до њих доводе, израженијаје (60\%) последица утицаја матерњег језика (језички/интерлингвални трансфер). Нађу ли се пред препреком на језику који уче или не препознају његове специфичности, ученици проналазе уточиште у већ формираним језичким навикама и обрасцима из српског и преносе их на енглески. Ово је нарочито видљиво тамо где не постоји потпуна значењска еквиваленција између лексичких јединица и тамо где се граматичке структуре ова два језика разликују. Као други узрок (40\%) показало сенедоследно коришћење правила енглеског језика и/или непрепознавање околности у којима се она примењују, као и непридржавање његових правописних норми (интралингвални трансфер). У овом смислу, од користи би било спровођење даљег истраживања којим би се са сигурношћу потврдио (или елиминисао) међујезички трансфер - упоређивањем грешака које говорници са различитим матерњим језицима праве на енглеском и др.

Одавно је прихваћен став да је неопходно обезбедити услове за несвесно усвајање Л2 кроз излагање језику, а мање се ослањати на свесно учење (Крешен 1982). Међутим, како је разумевање процес који се дешава непосредно пре усвајања (Робинсон и сарадници 2012: 253), неопходно је освестити ученике о конкретној проблематици, да би процес усвајања могао да наступи (Гес и Меки 2000: 203). Чини нам се да се ово нарочито односи на школско окружење где изложеност језику без скретања пажње на његове специфичности није довољна, посебно код ученика који још увек нису досегли напредну фазу учења Л2. Зато ученичке грешке не треба посматрати као негативну појаву, већ као њихово настојање да надоместе дефицит с којим су се суочили (Ленон 2008: 5) и где им је неопходна помоћ. Стога се надамо да се резултати овог истраживања могу искористити и применити у настави 
енглеског језика на датом узрасту, приликом одређивања адекватне дидактичке концепције, методичких приступа настави и наставног материјала, што би требало да учини да настава енглеског језика буде ефикаснија. Такође верујемо да би правовремено упућивање ученика на грешке довело до тога да се њихова учесталост редукује и спречи фосилизација у Л2.

Иако је истраживање вршено на узорку који чине ученици старијих разреда основне и средње стручне школе, чврсто верујемо да су резултати до којих смо дошли примењиви и на старије говорнике енглеског као страног језика чије су језичке компетенције ниже од Ц нивоа.

\section{ЛИТЕРАТУРА}

Барт 1975: M. K. Burt, Error analysis in the EFL classroom. TESOL Quarterly, 9, 53-63.

Вучо и Филиповић 2013: J. Vučo, J. Filipović, Serbian roadmap toward European plurilingualism. In: L. R. Miyares, M. R. Álvarez Silva, A. Muñoz Alvarado (eds.), Actualizaciones en comunicación social, vol. 1, Santiago de Cuba: Centro de Lingüística Aplicada, 157-160.

Гес и Меки 2000: S. M. Gass, A. Mackey, Stimulated recall methodology in second language research. Mahwah, NJ: Erlbaum.

Далеј и сарадници 1982: H. Dulay, M. Burt, S. Krashen, Language two. New York: Oxford University Press.

Душкова 1969: L. Duskova, On sources of errors in foreign language learning. International Review of Applied Linguistics, 7(1), 1-36.

Ђорђевић 2004: Р. Ђорђевић, Увод у контрастирање језика. Београд: Филолошки факултет, Чигоја штампа.

Елис 1994: R. Ellis, The study of second language acquisition. Oxford: Oxford University Press.

Керол 1966: J. В. Carroll, Research in foreign language teaching: The last five years. In: R. C. Mead Jr. (ed.), Language teaching broader contexts. Northeast Conference Reports on the Teaching of Foreign Languages: Reports of the Working Committee, New York: MLA Material Center, 12-42.

Кордер 1967: S. P. Corder, The significance oflearner's errors. International Review of Applied Linguistics in Language Teaching, 5(4), 161-170. 
Кордер 1981: S. P. Corder, Error analysis and interlanguage. Oxford: Oxford University Press.

Крешен 1982: S. Krashen, Principles and practice in second language acquisition. Oxford: Pergamon.

Ламберт 1966: W. A. Lambert, Some observations on first language acquisition and second language learning. Mimeograph.

Ленон 2008: P. Lennon, Contrastive analysis, error analysis, interlanguage. In: S. Gramley, V. Gramley (eds.), Bielefeld introduction to applied linguistics, Bielefeld Aisthesis, 51-60. [http://wwwhomes.unibielefeld.de/sgramley/CA-ErrorAnalysis-Interlang-Lennon.pdf]

Ли 1957: W. Lee, The linguistic context of language learning. English Language Teaching Journal, 11, 77-85.

Мишковић-Луковић 2015: М. Мишковић-Луковић, Прагматика. Крагујевац: Филолошко-уметнички факултет.

Полицер и Рамирес 1973: R. Politzer, A. Ramirez, An error analysis of the spoken English of Mexican-American pupils in a bilingual school and a monolingual school. Language Learning, 23(1), 39-61.

Ричардс и Шмит 2002: J. C. Richards, R. Schmidt, Dictionary of language teaching and applied linguistics ( $3^{\text {rd }} \mathrm{ed}$.). London: Longman.

Робинсон и сарадници 2012: P. Robinson, A. Mackey, S. Gass, R. Schmidt, Attention and awareness in second language acquisition. In: S. Gass, A. Mackey (eds.), The Routledge handbook of second language acquisition, New York: Routledge, 247-267.

Савет Европе 2001: Council of Europe, Common European framework of reference for languages: Learning, teaching, assessment. Cambridge: Cambridge University Press.

SrpKor2013: Корпус савременог српског језика, верзија SrpKor2013. Група за језичке технологије Универзитета у Београду, [http:// www.korpus.matf.bg.ac.rs]

Филиповић и сарадници 2007: J. Filipović, J. Vučo, Lj. Đurić, Critical review of language education policies in compulsory primary and secondary education in Serbia. Current Issues in Language Planning, 8(1), 222-242.

Хармер 2008: J. Harmer, How to teach English. Pearson Education Limited. Чомски 1966: N. Chomsky, Linguistic theory. In: R. C. Mead Jr. (ed.), Language teaching broader contexts. Northeast Conference Reports on the Teaching of Foreign Languages: Reports of the Working Committee, New York: MLA Material Center, 43-49.

Џејмс 1989: C. James, Errors in language learning and use: Exploring error analysis. London/New York: Routledge, Taylor \& Francis Group. 


\section{Irena Pantić \\ Ivan Petrović}

\section{LANGUAGE ERRORS THAT PRIMARY SCHOOL AND SECONDARY PROFESSIONAL SCHOOL STUDENTS MAKE IN THE ENGLISH LANGUAGE}

\section{Resume}

The paper aims to detect, classify, and investigate the most common errors that Serbian native students make in the course of learning English as a second language. It focuses on the final year primary school students (grades 7 and 8) and secondary professional school students, both of the public sector. The corpus was collected and extracted from the students' writings and divided into three types of errors - lexical-pragmatic (33\%), morphological-spelling (27\%), and syntactic (40\%) errors. Each group is represented by a series of examples. Beside the identification of the key errors among the pre-intermediate to intermediate students and tracing the origin of the errors, the research attempts to bring to light the matter of interference and implications of the existing mother tongue habits with the English language (interlingual transfer). Another source of errors was traced to be due to a misuse, and/or partial or faulty learning of a particular language rule of the target language (intralingual transfer). It also shows why the language errors need to be seen as a positive input - a helping tool to highlight and improve students' average formal and informal needs for communication in English. Therefore, we believe that our findings may serve teachers as support in their teaching practice, as a framework for lesson planning. It also may help teachers to conceive teaching materials and methodologies, and to gain some insight into students' learning process.

Key words: language error, language influence, English as a foreign language, Serbian as the mother tongue, language transfer, semantics. 